\title{
Analysis of urban cleanness agents' workstation on the appearance of Work Related Musculoskeletal Disorders
}

\author{
Leonildo Santos do Nascimento Júnior ${ }^{\mathrm{a},{ }^{*}}$ and Juliana da Costa Santos Pessoa ${ }^{\mathrm{b}}$ \\ ${ }^{a}$ Production and Systems Department, University of Minho, Azurém, 4800 - 058, Guimarães, Portugal \\ ${ }^{b}$ Physiotherapy Department, Universitary Center of João Pessoa (Unipê), BR 230 - Km 16, Água Fria, 58053- \\ 000, João Pessoa-PB, Brazil.
}

\begin{abstract}
This study had as objective to evaluate the workstation of the responsable for the collection of urban garbage in relation to the factors associates with the appearance or aggravation of WMRD, as well as identifying signals and symptoms of these illnesses in the related professionals. For this, was developed a form with open and closed questions, that approached item relative to the identification of the searched, to the organization and execution of the work and to the signals and symptoms of WMRD, e that was applied in 44 agents in a company of collection of urban residues in a Brazilian metropolis. As the results can be evidenced that between the factors that the cleanness' agents are susceptible to the appearance of WMRD can detach the lack of orientation of these professionals as the positions adopted in the work, the lack of training and qualification, as well as the repetitivity of tasks and not use of individual protection equipment. However, yet with the existence of innumerable factors of risk, evidenced a small incidence of pain.
\end{abstract}

Keywords: working conditions, WMRD, cleanness agent

*Corresponding author. E-mail: leonildofisio@gmail.com 


\section{Introduction}

The work is inseparable company of the man, being indispensable to the human condition and social life, because can generate power relations, property and social classes. Since the beginning of humanity, the man intends to accomplish through the work, because is through his job that he is recognized and valued in society [1]. However, sometimes the work is seen as source of wear, pain and fatigue, making with that appears in the individual a situation of discomfort, sacrifice and presence of disease, leading to a controversial concept of the emerging importance of work in human life. According [2] "the work becomes pathological when it becomes roots of suffering, that is, when the prescribed work is against the creative freedom runs the risk of a psychic and somatic instability, affecting the worker health."

The term WRMD (Work Related Musculoskeletal Disorders) refers to disorders or diseases affecting the musculoskeletal system, especially the neck and upper limbs, having a relationship, proven or not, with the work. About them, is explained that are diseases with occupational origin, resulting of a combination or not of several factors, such as repetitive use of muscle groups, maintenance of prolonged poor posture, ergonomically inadequate movements, poor management, temperature, vibration and others [3].

The origin of these disorders, most often, has no single cause. They are products of interactions between humans and their environment, with the presence of physical and psychological conditions that facilitate your occurrence, as well as a workplace that aggravates them.

In terms of the emerging of work-related diseases, prevention is associated as the most important measure and is reported as the main factor in relation to approaches relating to WRMD, as if had a specialized care in its initial phase, they would have their evolution interrupted or delayed. In this view preventive become necessary to consider aspects like the nature of activities, worker's training, interpersonal relationships and other factors that may interfere with the exposure, satisfaction, attitude and behavior of the worker.

For that the prevention would be real, it has an ergonomic science, since that the ergonomics studies various aspects such as posture and body movements, environmental factors (noise, vibration, lighting, climate and chemical agents), information, among others, in order to design safe, comfortable and efficient environments, at work and in everyday life [4].

The Brazilian Classification of Occupations [5] defines the activities of household garbage collector's as the professional responsible for "collecting junk in public places and other places, pouring them into vehicles and deposits appropriate in order to contribute to the cleanup of these places: walks through the neighborhoods, following preestablished routes to collect the garbage, dumps the trash heap or packed in cans, special trucks, cart or other deposit, using your own physical effort and hand tools to enable the transportation". This professional performs their work activities in an arduous situation and is often subject to a number of problems [6].

\section{Objectives}

The study had the objective to characterize the workplace of the responsible for the urban garbage collection in relation to factors associated with appearing or aggravation of Work-Related Musculoskeletal Diseases (WRMD's) and to identify signs and symptoms of these illnesses in these professionals.

\section{Methodology}

\subsection{Subjects}

Were interviewed 44 cleaning agents, employees of a company of urban garbage collect, of both sexes, with ages ranging from 30 to 64 years, that performed the work in the neighborhoods of João Pessoa, the capital of Paraiba, located in the Northeast - Brazil.

The research was approved by the ethics committee, as well as all subjects were informed about the procedures and signed a consent form.

\subsection{Interview protocol}

Was developed an interview form, based on information collected in $[3 ; 7]$ and was composed by 22 questions divided into three sections, the first section approached questions about the identification of the researched, being followed by those answered about the organization of the 
workplace and, finally, to the signs and symptoms of WRMD's.

\subsection{Procedures}

Once formulated, the interview scripts were applied with the sample that consented the study. The application of this instrument was performed by researchers with the purpose of guiding; clarifying the subjects or help them fill out when needed.

At the end, the results were analyzed and presented, then, through graphs and tables.

\section{Results}

The sample, in relation to gender, showed $50 \%$ were female and the remaining $50 \%$ were male. In what concerns the age, the group studied had an age range from 45 to 49 years, the incidence of which involves $31.8 \%$ of the sample.

On the level of schooling, $27.3 \%$ of the agents did not show any level of schooling, while $65.9 \%$ of the sample reported having completed a degree and only $6.8 \%$ have completed the 2 nd grade. This result are explains because the garbage collector usually has low education, and the most, those who are older in the profession, has the primary and often incomplete [7].

The figure 01 shows the distribution of the sample as working time in the company, is evidenced the high percentage (almost 60\%) of those who answered 16 to 20 years as average working time in that.

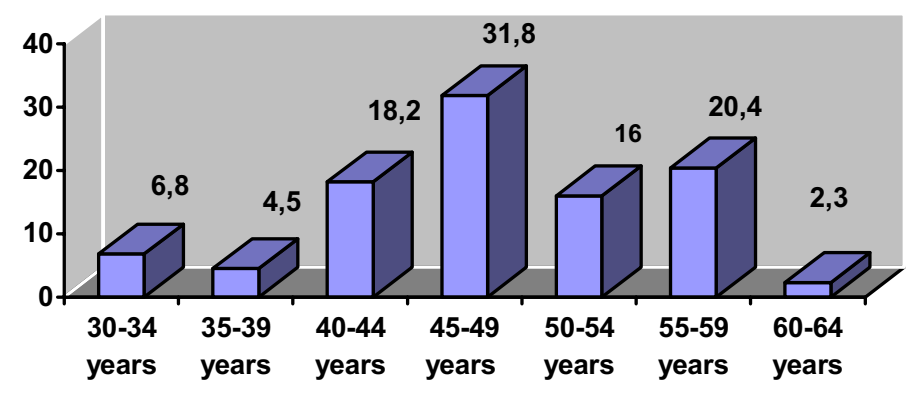

Figure 1 - Sample's distribution according the age.

In the matter involving the workday, the entire $(100 \%)$ said they work 8 daily hours. There was consensus, too, the approach to working hours, for all respondents $(100 \%)$, work from 6 to 10 hours and 12 to 16 hours, making, therefore, day labor.

Occurred for all workers involved in the research, said there was also working overtime, being paid by them. With respect to breaks during the work, the entire sample $(100 \%)$ claimed that there is a break from work, for the lunch hour and corresponds to 2 hours.

When asked if the work is repetitive (the same stretch of work, the same team and others), the most of the agents, with a total of $88.6 \%$, said they think their work as monotonous. This percentage is alarming and should be considered as a risk factor for onset of disease, because monotony can unchain fatigue, sluggishness, drowsiness and decreased level of attention.

According to the factor of feeling pressured by supervisors, when making your services, the vast majority, $75 \%$ of the total, said they do not feel persuaded, while the remaining $25 \%$ of agents said they work under pressure in most of the time. When the individual works without the pressure and constant supervision of the upper hierarchy produces even more and most motivated [3]. Also in this aspect, when asked about the degree of relationship with your supervisor, a portion of respondents, totaling $68.2 \%$, claimed to have good relationship, followed by $22.8 \%$ who claimed to have excellent relationship and finally, and bad or very bad with $4.5 \%$ each item. Levels of relationships between coworkers, there was a sharing of opinions, as all who responded to the interview, $56.8 \%$ qualified as good 
a relationship, $20.5 \%$ said excellent, followed by $18.2 \%$ who said they had bad relationship and $4.5 \%$ with very bad relationship.

On the guidelines for the exercise of his work there was an exact division, as 50\% reported having guidelines and $50 \%$ said they had no guidance, before or after he started working. In this job, "the main social risk related to this work process is the lack of adequate training of workers, making them powerless to demand preventive measures against accidents, infectious diseases and better working conditions "[6].

About the use of Personal Protective Equipment (PPE), 84\% of respondents said they have them, in contrast to $16 \%$ who said they did not, mainly because they do not need it, through the pursuit of lighter activity. And among those who reported having PPE, 56.8\% said they were using the same, since they are offered annually by the company, however, $43.2 \%$ said they did not use.

The figure 02 shows the considerations of cleaning agents about their working conditions and is detachable the fact a large number of them $(72.7 \%)$ say that have a good condition of work. About this, is cleaned that "when we work in conditions gratifying, we like the product made, some even fall in love with them (...), but when working overwhelmed, overwhelmed, we print angry in the product"[8]. Therefore, is evident that when happens a satisfaction in the work, results in a smaller cognitive and psychological burden, and eventually many diseases will be prevented.

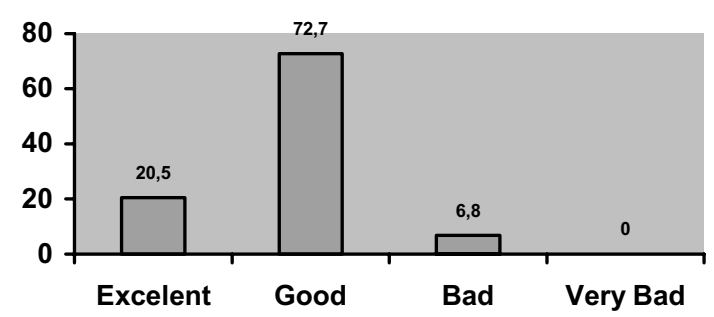

Figure 2 - Sample's distribution about work conditions.

In the sample, there was complaint of pain, for $36 \%$ of workers and during questioning about the relationship of pain with work, a little more than half, totaling $56.2 \%$, confirm the issue.

The Table 01 shows the locations indicated where the pain appears, a significant percentage appoint the lumbar spine, with $38 \%$ of the total, as well as the knee, with $25 \%$ and shoulder, with
$18.8 \%$ of responses affirmative. Something seemed occurred in other research, that there was great affection between sweepers are shoulders and arms pain, with $100 \%$, followed by knee and leg with $17.02 \%$ of respondents and the foot / ankle, dorsal and lumbar region, appears at $10.63 \%$ [7].

Table 1

Painful symptoms by body region

\begin{tabular}{|l|l|l|}
\hline Joint & Number of Agents & Percentile \\
\hline Shoulder & 3 & $18,8 \%$ \\
\hline Arm & 1 & $6,3 \%$ \\
\hline Hip & 2 & $12,5 \%$ \\
\hline Knee & 4 & $25 \%$ \\
\hline Ankle & 1 & $6,3 \%$ \\
\hline Lower Back & 6 & $38 \%$ \\
\hline Dorsal Region & 2 & $12,5 \%$ \\
\hline
\end{tabular}

The data presented in Table 2 show the posture adopted by the cleaning agents when perform their activities.

Table 2

Postures adopted during the work

\begin{tabular}{|l|l|l|l|l|l|l|}
\hline \multirow{2}{*}{ Posture } & \multicolumn{2}{|l|}{ Yes } & \multicolumn{2}{l|}{ No } & \multicolumn{2}{l|}{ Sometimes } \\
\cline { 2 - 7 } & N & \% & N & $\%$ & N & $\%$ \\
\hline Fixed Torso & 14 & 31,8 & 22 & 50 & 8 & 18,2 \\
\hline Torso Twists & 30 & 68,2 & 12 & 27,3 & 2 & 4,5 \\
\hline Torso Pushups & 20 & 45,5 & 13 & 29,6 & 11 & 24,9 \\
\hline Cervical Flexion & 30 & 68,2 & 7 & 15,9 & 7 & 15,9 \\
\hline
\end{tabular}

The muscle fatigue appears when in a maintaining fixed posture occurs when the posture is held for long periods due to the exposure of muscles to isometric contractions [3]. And, about movements of the trunk and neck flexion, doing them too much, the cervical and lumbar spine structures may have overloaded due to excessive curvature, and the future, there may be complaints of back pain [9].

\section{Conclusions}

In this framework, we can conclude that there is a need for consideration of the search for such factors as the nature of activities, worker training, interpersonal relationships and others that 
may interfere with the exposure, satisfaction, attitude and behavior of the worker against the WRMD's.

\section{References}

[1] H. Braverman. Trabalho e Capital Monopolista. $3^{\text {a }}$ ed., Rio de Janeiro: Guanabara Koogan, 1987.

[2] C. Dejours. A loucura do trabalho: estudo de psicopatologia do trabalho. 5.ed. SãoPaulo, Cortez, 1992.

[3] P. C. P. Deliberato. Fisioterapia Preventiva: fundamentos e aplicações. $1^{\mathrm{a}}$ ed. São Paulo: Manole, 2002.

[4] J. Dul; B. Weerdmeester; trad. Itiro Iida. Ergonomia Prática. $2^{a}$ ed. São Paulo: Edgard Blucher, 2004.

[5] Ministério do Trabalho e Emprego. Classificação Brasileira de Ocupação - C.B.O. Lixeiro $\mathrm{n}^{\circ}$ 55260. Disponível em: $<$ http://www.mtecbo.gov.br> Acesso em: 15 Ago. 2008.
[6] M. P. Velloso; E.M. Santos; L. A. Anjos. Processo de trabalho e acidentes de trabalho em coletores de lixo domiciliar na cidade do Rio de Janeiro, Brasil. Cad. Saúde Pública, Out 1997, vol.13, n. 4, p. 693-700.

[7] R.B. Madruga. Cargas de trabalho encontradas nos coletores de lixo domiciliar - um estudo de caso. Florianópolis, 2002. 70f. Dissertação (Mestrado em Engenharia de Produção) Departamento de Engenharia de Produção, Universidade Federal de Santa Catarina.

[8] W. Codo.; M. C. G. Almeida. LER - diagnóstico, tratamento e prevenção: uma abordagem interdisciplinar. 4. ed. Petrópolis: Vozes, 1998.

[9] V. Lima. Ginástica laboral: atividade física no ambiente de trabalho. 3. ed. São Paulo: Phorte, 2007. 